\title{
A Role for cGMP During Tetanus Toxin Blockade of Acetylcholine Release in the Rat Pheochromocytoma (PC12) Cell Line
}

\author{
Kathryn Sandberg, ${ }^{a}$ Cathy J. Berry, Erica Eugster, and Terry B. Rogers \\ Department of Biological Chemistry, University of Maryland School of Medicine, Baltimore, Maryland 21201
}

In order to identify the specific molecular mechanisms involved in neurosecretion, we investigated the mechanism of action of tetanus toxin, a potent presynaptic neurotoxin, in the rat adrenal pheochromocytoma PC12 cell line. It has recently been reported that tetanus toxin is a potent inhibitor of the release of depolarization-evoked ${ }^{3} \mathrm{H}$-acetylcholine (ACh) from nerve growth factor-differentiated PC12 cells (Sandberg et al., 1989a). In PC12 cells, as in many neural tissue preparations, cGMP accumulation in intact cells increased 6- to 17-fold when stimulated with veratridine (200 $\mu \mathrm{M})$, carbachol (1 $\mathrm{mm}), \mathrm{Ba}^{2+}(2 \mathrm{mM})$, or $\mathrm{K}+(30 \mathrm{~mm})$. Preincubation of the cells with tetanus toxin inhibits this accumulation by greater than $95 \%$. The toxin dose-inhibition curves for ${ }^{3} \mathrm{H}-\mathrm{ACh}$ release and CGMP accumulation are similar, with half-maximal doses of tetanus toxin seen at approximately $5 \mathrm{~nm}$. The time courses for the development of the effects of tetanus on ${ }^{3} \mathrm{H}-\mathrm{ACh}$ release and on CGMP accumulation were also similar. Protocols which elevated intracellular CGMP levels reversed the action of the toxin. For example, evoked $A C h$ release was restored in intoxicated PC12 cells by a 15 min exposure to $100 \mu \mathrm{M}$ 8-bromo-cGMP. The half-maximal dose was observed at $50 \mu \mathrm{M}$ nucleotide. Examination of the nucleotide specificity revealed that only cyclic guanine analogs were effective in reversing the effects of tetanus toxin. These results suggested that the inhibition of depolarization-evoked CGMP accumulation is causally related to the action of tetanus toxin on neurosecretion. This hypothesis was supported by the observation that phosphodiesterase inhibitors were able to restore depolarization-evoked cGMP accumulation and ${ }^{3} \mathrm{H}-\mathrm{ACh}$ release in tetanus-treated PC12 cultures. Zaprinast, an inhibitor of cGMP-degrading phosphodiesterases, completely reversed the effects of tetanus toxin on these parameters, while 3-methyl-1-isobutyl methylxanthine was partially effective. Taken together, these results support the view that the underlying mechanism of action of tetanus toxin is related to alterations in CGMP metabolism in PC12 cells. Tetanus toxin should prove to be a valuable probe in identifying this process.

\footnotetext{
Received Mar. 13, 1989; revised June 12, 1989; accepted June 13, 1989.

This work was supported by a contract from the U.S. Army Medical Research and Development Command (DAMD-17-86-C-6160).

Correspondence should be addressed to Dr. Terry B. Rogers, Department of Biological Chemistry, University of Maryland School of Medicine, 660 West Redwood Street, Baltimore, MD 21201.

a Present address: Bldg. 10, Rm. 8C-407, NICHD, 9000 Rockville Pike, Bethesda, MD 20892.

Copyright (C) 1989 Society for Neuroscience $0270-6474 / 89 / 113946-09 \$ 02.00 / 0$
}

Chemical communication of signals across the synaptic cleft is a crucial process in the nervous system. However, the molecular mechanisms that underlie neurotransmitter release from the presynaptic terminal are poorly understood. It would be valuable to have specific biochemical probes that could "dissect" the excitation-secretion process into discrete steps, thus allowing identification of the molecular events occurring in neurotransmission.

Tetanus toxin, a protein produced by the bacterium Clostridium tetani, is an extremely potent neurotoxin (for reviews, see Habermann and Dreyer, 1986; Simpson, 1986). It is well documented that tetanus toxin inhibits neurotransmitter release from presynaptic terminals in many neuronal preparations, including the neuromuscular junction, primary cultured neurons, brain slices, and synaptosomes (Schmitt et al., 1981; Bergey et al., 1983; Osborne and Bradford, 1973). Although the mechanism of action of tetanus is unknown, it is clear that the toxin does not (1) cause cell death or disrupt the ultrastructure of the presynaptic terminal (Schwab and Thoenen, 1976; Mellanby and Green, 1981); (2) affect the synthesis, storage, or uptake of neurotransmitter (Collingridge et al., 1980); or (3) alter presynaptic calcium currents (Dreyer et al., 1983). These results suggest that the action of tetanus toxin involves direct perturbations of the excitation-secretion process. Taken together, the accumulating evidence indicates that tetanus toxin is a valuable probe for studying mechanisms of neurosecretion.

Recent results from our laboratory have demonstrated that the rat pheochromocytoma cell line, $\mathrm{PC12}$, is sensitive to tetanus toxin (Walton et al., 1988; Sandberg et al., 1989a). The toxin binds to high-affinity receptors on cultures of NGF-treated PC12 cells (Walton et al., 1988). Further, subnanomolar doses of tetanus toxin inhibit stimulus-evoked ACh release from these cultures (Sandberg et al., 1989a). The toxin was rapidly internalized $\left(t \frac{1}{2}=4 \mathrm{~min}\right)$, and after a lag period, which is inversely related to the toxin concentration, evoked ACh release is inhibited (Sandberg et al., 1989a). These findings support the 3-step model proposed for tetanus toxin action in nervous tissues (Schmitt et al., 1981; Simpson, 1986) and reveal that the PC12 cell line is a valid model system for studying the molecular mechanism of action of tetanus toxin.

The present report extends these previous studies to an examination of the biochemical effects of tetanus toxin on PC12 cells. The major results are that tetanus toxin attenuates stimulus-evoked elevation of cGMP levels in a dose- and timedependent fashion that parallels the inhibition of ACh release. Further, the inhibitory effects of tetanus can be rapidly reversed by application of either cGMP analogs or inhibitors of cGMPdegrading phosphodiesterases. These results provide new insight 
into the mechanism of action of tetanus and support the view that tetanus toxin acts by interfering with cGMP metabolism. A preliminary report of this study has previously been published (Sandberg et al., 1989b).

\section{Materials and Methods}

Materials. Tetanus toxin was purchased from the Department of Public Health, Commonwealth of Massachusetts (N. Jamaica Plains, MA) or was kindly supplied to us by Dr. R. O. Thomson of Wellcome Research Laboratories (Beckenham, England). The toxin was stored lyophilized or frozen in PBS, $0.25 \%$ BSA at $-70^{\circ} \mathrm{C}$. DMEM, fetal calf serum and horse serum were purchased from Hazelton Dutchland (Denver, PA). Bio-Rad protein assay dye was purchased from Bio-Rad (Rockville Centre, NY). Toluene Pure Solv and Permablend (PPO 98\%; POPOP, $2 \%$ ) were purchased from Packard Instrument Co., Inc. (Downers Grove, IL). Collagen used for coating the culture dishes was obtained from Flow Laboratories, Inc. (McLean, VA). Horse tetanus antitoxin was purchased from Sclavo Labs (Wayne, NJ). Sodium tetraphenylboron was purchased from Aldrich Chem. Co. (Milwaukee, WI). cAMP, cGMP, 8-Br-cGMP, 8-Br-cAMP, $N^{6}, 2^{\prime}$-dibutyryl-cGMP, $N^{6}, 2^{\prime}$-dibutyryl-cAMP, 8-Br-guanosine, 8-Br-inosine cyclic monophosphate, $O^{2}$-monobutyrylcGMP, $N^{2}$-monobutyryl-cGMP, $O^{2}$-monobutyryl-cAMP, $N^{2}$-monobutyryl-cAMP, dexamethasone, alumina oxide, choline kinase, choline, veratridine, IBMX, and BSA were obtained from Sigma Chemical Co. (St. Louis, MO). ${ }^{3} \mathrm{H}-\mathrm{Ch}$ and cGMP radioimmunoassay kits werc purchased from New England Nuclear (Boston, MA). The following tissue culture plasticware was used: $75 \mathrm{~cm}^{2}$ Corning tissue culture flasks, 35 $\mathrm{mm}$ Nunc multiwell plates, and $35 \mathrm{~mm}$ Nunc petri dishes.

PC12 cell cultures. PC12 cells were obtained from Dr. Lee Eiden (NIH, Bethesda, MD). PC12 cells were cultured on collagen-coated tissue cultureware as previously described (Sandberg et al., 1989a). In brief, $\mathrm{PC} 12$ cells were maintained by subculturing weekly at $5 \times 10^{5}$ cells per $75 \mathrm{~cm}^{2}$ flask. The medium, DMEM, was supplemented with $7.5 \%$ fetal calf serum and $7.5 \%$ horse serum. The PC12 medium was exchanged every $2-3 \mathrm{~d}$.

cGMP determinations. Unless otherwise specified, PC1 2 cells were grown in the presence of NGF for at least $8 \mathrm{~d} ; 16-18 \mathrm{hr}$ before experiments, tetanus toxin was added to the cultures in DMEM containing $1 \%$ fetal calf serum and NGF $(100 \mathrm{ng} / \mathrm{ml})$. At the end of this incubation, the PC12 cells were washed by replacing the media with $1 \mathrm{ml}$ DMEM. Unless otherwise described, the wash media was supplemented with $100 \mu \mathrm{M}$ IBMX. After a $2 \mathrm{~min}$ incubation at $37^{\circ} \mathrm{C}$, this wash media was removed and $\mathrm{ACh}$ release buffer was added. The release buffer was: 110 $\mathrm{mm} \mathrm{NaCl}, 5.5 \mathrm{~mm} \mathrm{KCl}, 2 \mathrm{~mm} \mathrm{Na} \mathrm{PO}_{4}, 1.8 \mathrm{~mm} \mathrm{CaCl}, 1 \mathrm{~mm} \mathrm{MgCl}$, $25 \mathrm{~mm}$ glucose, $70 \mathrm{~mm}$ sucrose, $340 \mathrm{mOsm}, \mathrm{pH}$ 7.4. In order to measure evoked release, the cells were exposed to depolarizing buffer [release buffer supplemented with one of the following: $30 \mathrm{mM} \mathrm{KCl}$ (in this case, the $\mathrm{NaCl}$ concentration was reduced to maintain constant osmolarity); $1 \mathrm{~mm}$ carbachol; $200 \mu \mathrm{M}$ veratridine; or $2 \mathrm{~mm}$ barium chloride (in this case, the barium chloride replaced the calcium chloride)]. The cells were incubated with these buffers for various times as indicated in the text. The incubations were terminated by aspirating the buffers and rapidly adding $750 \mu \mathrm{l}$ of icc-cold $6 \%$ TCA to each wcll. The wells were scraped with a rubber policeman, and the suspensions were centrifuged for 5 $\mathrm{min}$ at $12,000 \times \mathrm{g}$. The pellets were used to quantitate protein from each well by resuspending each in $0.5 \mathrm{ml}$ of $0.00125 \%$ SDS, $0.5 \mathrm{~N}$ $\mathrm{NaOH}$ and analyzing the samples in a BioRad protein assay using BSA as a standard. cGMP in the TCA-soluble fraction was measured using a radioimmunoassay method. It was found that further fractionation of the samples improved the precision of the assay. TCA extracts were applied to columns containing $2 \mathrm{ml}$ of Dowex AG50-X4 $\left(\mathrm{H}^{+}\right.$form) which were previously equilibrated with $\mathrm{H}_{2} \mathrm{O}$. The columns were washed with $3 \mathrm{ml}$ of $0.1 \mathrm{~N} \mathrm{HCl}$ followed by $2 \mathrm{ml}$ of distilled water. cGMP was eluted in the following $1.5 \mathrm{ml}$ of distilled water. The cGMP fractions were lyophilized, and the lyophilisate was dissolved in $50 \mathrm{~mm} \mathrm{Na}$ acetate, $\mathrm{pH}$ 6, before radioimmunoassay. cGMP levels were measured using New England Nuclear radioimmunoassay kits and were corrected for recovery, which was assessed by adding ${ }^{3} \mathrm{H}-\mathrm{cGMP}$ to the samples at the onset of the experiment. The recovery was typically between $70-85 \%$ and the cGMP levels were normalized to protein from each cell culture well.

In several experiments described in Results, both ${ }^{3} \mathrm{H}-\mathrm{ACh}$ release and intracellular cGMP levels were quantitated from the same culture well of $\mathrm{PC} 12$ cells. It was possible to obtain both of these values from the same cells by first performing the ${ }^{3} \mathrm{H}$-ACh release protocol using ${ }^{3} \mathrm{H}$ $\mathrm{Ch}$-prelabeled cells as described below. Immediately after the release, buffer was removed (in this case, release buffer was supplemented with $30 \mu \mathrm{M}$ eserine) from the culture dish for ${ }^{3} \mathrm{II}-\mathrm{ACh}$ quantitation, $750 \mu \mathrm{l}$ of $6 \%$ TCA was added to the dish and cGMP levels were assayed as described above.

$A C h$ release. After treatment of $\mathrm{PC} 12$ cells with the specified release buffers (see above for details), ${ }^{3} \mathrm{H}-\mathrm{ACh}$ release was measured from cells that had been prelabeled with ${ }^{3} \mathrm{H}-\mathrm{Ch}$ as previously described (Sandberg et al., 1989a). In brief, the ${ }^{3} \mathrm{H}-\mathrm{ACh}$ released was separated from any free ${ }^{3} \mathrm{H}$-Ch by first phosphorylating the free ${ }^{3} \mathrm{H}$-Ch with choline kinase. ${ }^{3} \mathrm{H}$-ACh was separated from the ${ }^{3} \mathrm{H}$-phosphoryl- $\mathrm{Ch}$ and quantitated by 2 methods. In the first method, ${ }^{3} \mathrm{H}$ - $\mathrm{ACh}$ was extracted with $\mathrm{Na}$ tetraphenylboron into an organic phase containing scintillant. Because elevated $\mathrm{K}^{+}$interfered with this extraction procedure, a second method was developed so that $\mathrm{K}^{+}$-stimulated ${ }^{3} \mathrm{H}$-ACh release could be measured. In this approach, the release media was incubated with choline kinase, and the reaction solution $(1 \mathrm{ml})$ was added to ion-exchangc columns containing $8 \mathrm{ml}$ of Bio Rad AG1-X8 (formate form) equilibrated with $\mathrm{H}_{2} \mathrm{O}$. The columns were washed with $1 \mathrm{ml}$ of $50 \mathrm{~mm}$ Tris$\mathrm{HCl}, \mathrm{pH} 8$, and then the ${ }^{3} \mathrm{H}-\mathrm{ACh}$ was eluted with $2 \mathrm{ml}$ of the same buffer and counted using scintillation methods. Pilot experiments revealed that the ${ }^{3} \mathrm{H}$-ACh was well resolved from ${ }^{3} \mathrm{H}$-phosphoryl-Ch under these conditions.

Guanylate cyclase assay. PC12 cells were removed from the culture dishes by gentle scraping with a rubber policeman and then collected by centrifugation. The cells were homogenized in $0.25 \mathrm{M}$ sucrose, 20 mM Tris- $\mathrm{HCl}, 10 \mathrm{~mm}$ mercaptoethanol, $1 \mathrm{~mm}$ EDTA, $\mathrm{pH} 7.4$, in a Teflon glass homogenizer. Soluble and particulate fractions were obtained by centrifuging the homogenate at $100,000 \times \mathrm{g}$. Guanylate cyclase activity was assessed by quantitating the conversion of $\alpha-^{32} \mathrm{P}-\mathrm{GTP}$ to ${ }^{32} \mathrm{P}-\mathrm{cGMP}$ in vitro. The final reaction mixture containcd $60 \mathrm{nmol}$ $\alpha{ }^{32} \mathrm{P}$-GTP $(0.02 \mu \mathrm{Ci} / \mathrm{nmol}), 0.3 \mu \mathrm{mol} \mathrm{MnCl}, 30 \mu \mathrm{mol}$ Tris- $\mathrm{HCl}, \mathrm{pH}$ 7.7 , and $15 \mu \mathrm{g}$ protein (soluble fraction) or $50 \mu \mathrm{g}$ protein (particulate fraction) in a total volume of $150 \mu \mathrm{l}$. After the mixture was incubated for $15 \mathrm{~min}$ at $30^{\circ} \mathrm{C}$ with constant shaking, the reaction was stopped by heating for $2 \mathrm{~min}$ in a boiling water bath. The ${ }^{32} \mathrm{P}$-cGMP was isolated by ion-exchange chromatography. The reaction mixture was eluted through an Alumina column ( $1 \mathrm{ml}$ of resin equilibrated with $\mathrm{H}_{2} \mathrm{O}$ ) with $5 \mathrm{ml}$ Tris- $\mathrm{HCl}$. The eluate flowed directly onto a second column filled with Dowex AG-1 $(1.5 \mathrm{ml})$ that had been pretreated with $5 \mathrm{ml} 1 \mathrm{~N}$ formic acid and then $10 \mathrm{ml} \mathrm{H} \mathrm{H}_{2} \mathrm{O}$. Then the column was washed sequentially with $4 \mathrm{ml} 50 \mathrm{~mm}$ Tris- $\mathrm{HCl}, \mathrm{pH} 7.4,10 \mathrm{ml}$ of $50 \mathrm{~mm}$ formic acid, $3 \mathrm{ml} 0.2 \mathrm{M}$ ammonium formate in $4 \mathrm{~N}$ formic acid, and finally with $10 \mathrm{ml}$ of the ammonium formate solution. Pilot experiments demonstrated that $75-85 \%$ of the cGMP was recovercd in this final fraction. This assay was found to be linear with respect to tissue and time (20 min). All assays were performed within this linear range.

\section{Results}

cGMP accumulation in response to depolarizing stimuli

It is well documented that intracellular cGMP levels rise when neuronal tissues are depolarized (Nathanson, 1977; Ferrendelli et al., 1978; Study et al., 1978). When PC12 cells were depolarized with veratridine, potassium, carbachol, or barium, cGMP levels were increased 7- to 12-fold (Fig. 1). These time-course studies reveal that there is a transient response of the cells to most of the depolarizing conditions; cGMP rapidly increases, reaching a maximum within $10-30 \mathrm{sec}$, which is followed by a declining phase in which the cyclic nucleotide decreases to control values. Barium evoked a slower and more sustained cGMP response. The reason for this difference is not clear.

The declining phase in the cGMP response may be due to its degradation by phosphodiesterases. This is supported by results from experiments in which IBMX was added. As shown in Figure 1 (inset), brief preincubation ( $2 \mathrm{~min}$ ) with IBMX significantly decreased the rate of the decline in cGMP levels after depolarization. Although maximal levels of cGMP were not altcred under these short incubation conditions, this maximal level was stabilized. This plateau of cGMP was more easily 


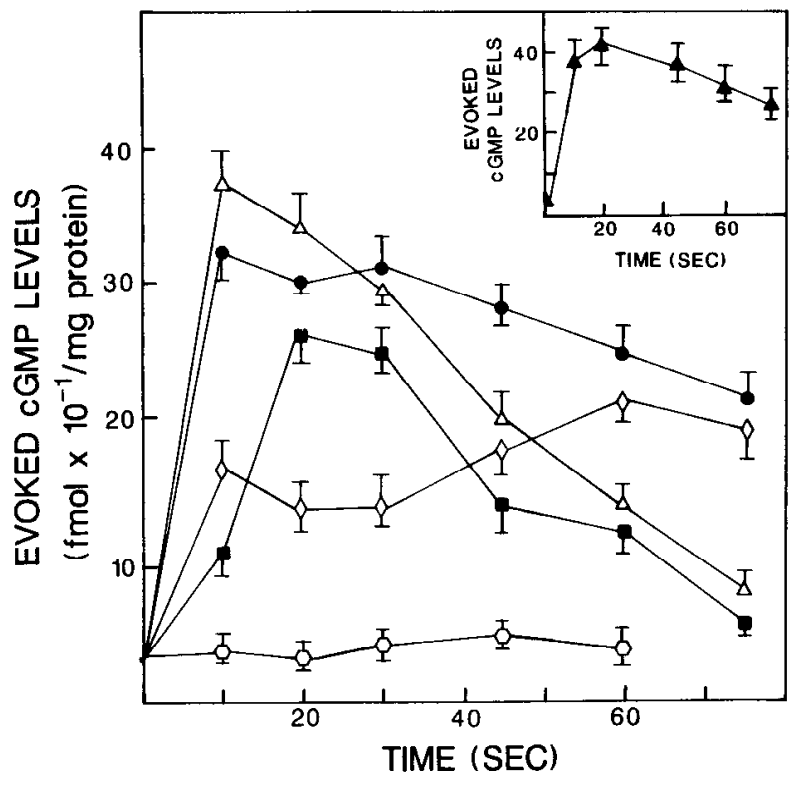

Figure 1. Time course of stimulus-induced cGMP levels in PC1 2 cells. Shown are the cGMP levels when the cells were exposed to buffer $(0)$ or buffer supplemented with $200 \mu \mathrm{M}$ veratridine (D), $1 \mathrm{mM}$ carbachol $(\Delta), 2 \mathrm{mM} \mathrm{BaCl}_{2}(\diamond)$, or $30 \mathrm{~mm} \mathrm{KCl}(\diamond)$. Inset, Time course for cultures treated with carbachol. Cultures were treated in an identical manner except for a 2 min preincubation with $100 \mu \mathrm{M}$ IBMX. These results are the means of 2-3 experiments, each performed in sextuplicate ( \pm SEM).

measurable and sample-to-sample variability was greatly diminished. Thus, this brief IBMX treatment was included in the experiments described below.

Muscarinic receptor activation leads to the production of cGMP in several cell systems (Goldberg and Haddox, 1977; Snider et al., 1984). It is possible that the increases in cGMP observed in $\mathrm{PC} 12$ cells result directly from depolarization or indirectly from ACh release and subsequent stimulation of muscarinic receptors present on PC12 cells (Green and Tischler, 1982). To distinguish between these alternative mechanisms, cells were depolarized with potassium in the presence of a cholinergic antagonist, atropine. As shown in Table 1, atropine had no effect on the cGMP response. Thus, as previously reported by Snider et al. (1984) for N1E-115 cells, cGMP elevation is a response to depolarization rather than to the action of $\mathrm{ACh}$ released upon depolarization.

Evoked ${ }^{3} \mathrm{H}-\mathrm{ACh}$ release and cGMP accumulation were measurcd in the same cultures following depolarization by a variety of secretagogues. There was some variability in cGMP levels

\begin{tabular}{lccc}
\hline $\begin{array}{l}\text { Table 1. Effect of atropine on potassium-induced cGMP } \\
\text { accumulation }\end{array}$ & \\
& $\begin{array}{l}\text { Intracellular cGMP levels } \\
\text { (fmol } \times 10^{-1} / \mathrm{mg} \text { protein) }\end{array}$ & \\
\cline { 2 - 3 } $\begin{array}{l}\text { Incubation } \\
\text { conditions }\end{array}$ & Control & Atropine & \% Control \\
\hline Basal & $12 \pm 0.4$ & $14 \pm 0.4$ & 117 \\
$30 \mathrm{mM} \mathrm{KCl}$ & $165 \pm 12$ & $159 \pm 14$ & 96
\end{tabular}

Prior to depolarization, the cells were incubated with $1 \mu \mathrm{M}$ atropine for $15 \mathrm{~min}$ as indicated. Following this preincubation, the cells were either stimulated with $30 \mathrm{mM} \mathrm{KCl}$ at $37^{\circ} \mathrm{C}$ for $1 \mathrm{~min}$ or left in normal release buffer. cGMP levels were then determined. Results are the means of 2-3 experiments, each performed in sextuplicate \pm SEM.
Table 2. Effect of tetanus toxin on cGMP levels

\begin{tabular}{lccc} 
Incubation & \multicolumn{2}{l}{$\begin{array}{l}\text { Intracellular cGMP levels } \\
\text { (fmol } \times 10^{-1} / \mathbf{m g} \text { protein) }\end{array}$} & \\
\cline { 2 - 3 } conditions & Control & Toxin & \% Control \\
\hline Basal & $11 \pm 0.7$ & $12 \pm 0.6$ & - \\
Veratridine & $42 \pm 1.5$ & $24 \pm 0.5$ & 39 \\
Carbachol & $48 \pm 2.7$ & $25 \pm 0.7$ & 35 \\
Barium & $85 \pm 5.0$ & $27 \pm 0.6$ & 20 \\
Potassium & $117 \pm 7.8$ & $51 \pm 3.1$ & 37
\end{tabular}

PC12 cell cultures were incubated without (Control) or with $10 \mathrm{nM}$ tetanus toxin for $16 \mathrm{hr}$ at $37^{\circ} \mathrm{C}$. At the end of this incubation, the cells were washed and then stimulated for $2 \mathrm{~min}$ at $37^{\circ} \mathrm{C}$ with either $200 \mu \mathrm{M}$ veratridine, $1 \mathrm{~mm}$ carbachol, 2 $\mathrm{mM} \mathrm{BaCl}_{2}$, or $30 \mathrm{~mm} \mathrm{KCl}$ as indicated. At the end of this incubation, intracellular levels of cGMP were measured. The values are the means of 2-3 experiments, each performed in sextuplicate $( \pm$ SEM).

and the magnitude of $\mathrm{ACh}$ release between cultures. Accordingly, it was advantageous to develop methods which permitted measurement of both parameters in the same well. As shown in Figure 2, there was a correlation between the 2 parameters in response to the depolarizing stimuli. Because of the methods that had to be employed, there was an inherent difference in the timing of these determinations: $\mathrm{ACh}$ release is the total release over $2 \mathrm{~min}$, while cGMP levels were measured at $2 \mathrm{~min}$. Therefore, these results provide qualitative evidence that the 2 effects are related.

\section{Tetanus toxin blocks depolarization-induced cGMP accumulation}

When PC12 cells were treated with $10 \mathrm{~nm}$ tetanus toxin, there was a marked reduction in the depolarization-induced increase in cGMP regardless of the stimulus (Table 2). In contrast, no detectable effect of toxin was seen on the basal levels of cGMP under these experimental conditions. Control experiments revealed that these effects were specific to tetanus toxin. Heatinactivated toxin, toxin preincubated with toxin antibody, or tetanus toxoid were all ineffective at reducing the accumulation of cGMP in response to depolarizing stimuli (data not shown).

The inhibitory effects of tetanus toxin on cGMP accumulation were dose dependent (Fig. 3). Figure 3 also shows that this doseresponse relation is very similar to that observed for the effects of tetanus toxin on the inhibition of evoked ${ }^{3} \mathrm{H}-\mathrm{ACh}$ release from these same cells. In these experiments, the half-maximal dose of tetanus toxin for inhibition of evoked ${ }^{3} \mathrm{H}-\mathrm{ACh}$ release was $5 \mathrm{nM}$, while the half-maximal effect of toxin on cGMP accumulation was observed at $4.5 \mathrm{nM}$.

We have previously reported that the time course for the development of inhibitory effects of $10 \mathrm{~nm}$ tetanus toxin on ACh release has a characteristic $1 \mathrm{hr}$ lag phase (Sandberg et al., 1989a). As shown in Figure 4, the time course for the appearance of the inhibitory effects of tetanus toxin on cGMP accumulation and $\mathrm{ACh}$ release are similar. Both responses display a lag phase followed by the rapid onset of inhibition. The half-maximal effects on cGMP accumulation and ACh release occur at approximately 2 and $3 \mathrm{hr}$, respectively. Taken together, these results suggest that the attenuation of cGMP levels and ${ }^{3} \mathrm{H}-\mathrm{ACh}$ release in PC12 cells are related.

\section{Effect of cell differentiation}

Wc have previously demonstrated that the differentiation state of PC12 cultures was a critical factor in the development of 


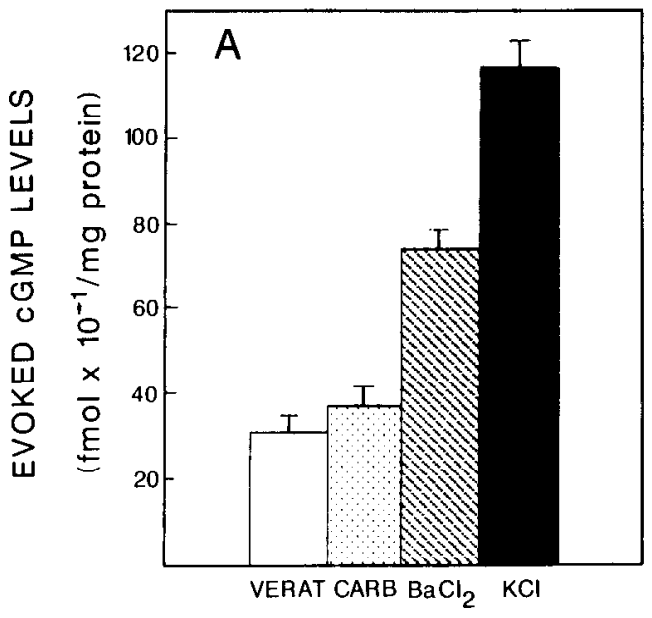

INCUBATION CONDITIONS

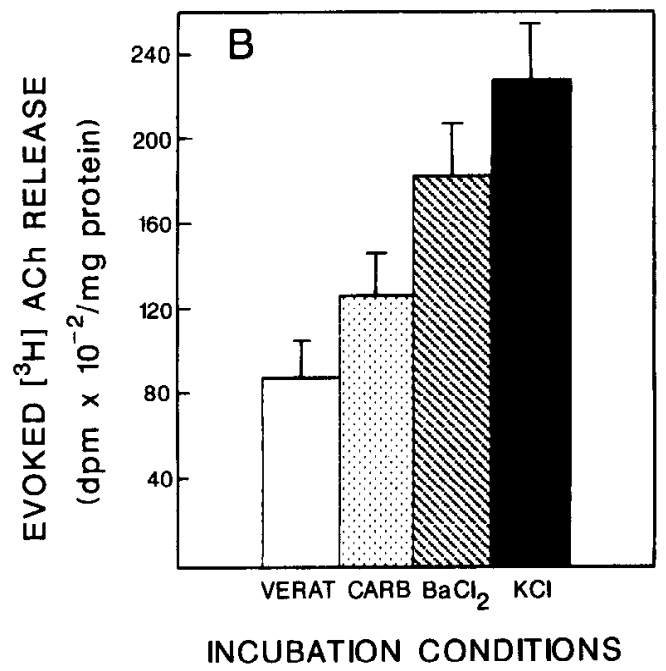

Figure 2. Effect of various stimuli on stimulus-evoked cGMP levels and evoked ACh rclcasc in PC1 2 cultures. The cells were depolarized with various stimuli for $2 \mathrm{~min}$ at $37^{\circ} \mathrm{C}$. The incubations were terminated and ${ }^{3} \mathrm{H}$-ACh release and intracellular cGMP levels were determined from the same culture wells. $A$, cGMP levels are shown for cells stimulated with $200 \mu \mathrm{M}$ veratridine (open bar), $1 \mathrm{mM}$ carbachol (stippled bar), $2 \mathrm{~mm} \mathrm{BaCl}$, (hatched bar), or $30 \mathrm{~mm} \mathrm{KCl} \mathrm{(solid} \mathrm{bar).} \mathrm{B,} \mathrm{Levels}$ of evoked release of ${ }^{3} \mathrm{H}$-ACh from the same cultures. The designations of the histogram are the same as described in $A$. These results are the means of 2-3 experiments, each performed in sextuplicate $( \pm$ SEM).

sensitivity of ACh rclease to tctanus toxin (Sandberg et al., 1989a). Experiments were performed to determine if toxin-mediated inhibition of evoked cGMP levels was related to differentiation as well. The cells were cultured under conditions known to stimulate distinct forms of differentiation as previously described (Walton et al., 1988; Sandberg et al., 1989a): nondifferentiated, low density for $7 \mathrm{~d}$ (SPARSE); glucocorticoid treatment, in the presence of dexamethasone for $14 \mathrm{~d}$ (DEX); NGF for $14 \mathrm{~d}$ (NGF); autodifferentiated, high density for $7 \mathrm{~d}$ (DENSE). As shown in Figure 5, tetanus toxin blocked barium-evoked cGMP elevation and ${ }^{3} \mathrm{H}-\mathrm{ACh}$ release only in cultures treated with NGF. It is interesting to observe that evoked cGMP levels varied with the differentiation state. This was not the direct result of guanylate cyclase expression since we have previously reported that the soluble and particulate enzyme activities are comparable in the different cultures (Eugster et al., 1986).

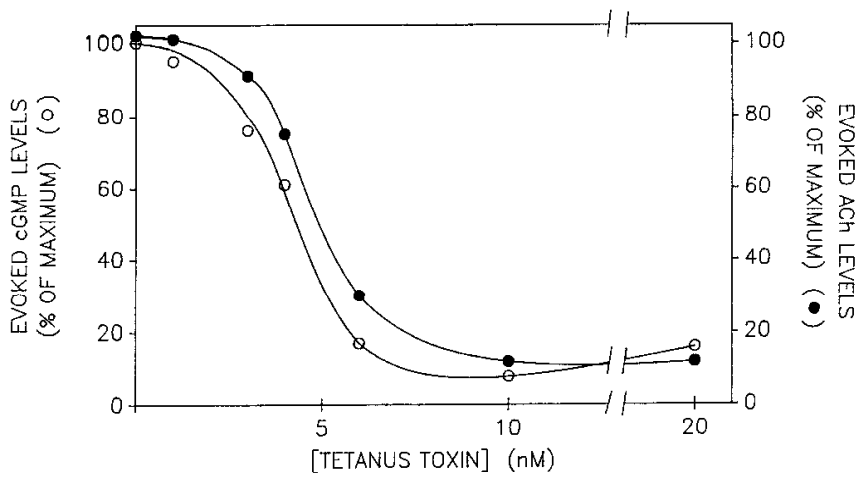

Figure 3. Dose-response curve of tetanus toxin action on $\mathrm{K}^{+}$-stimulated ${ }^{3} \mathrm{H}-\Lambda \mathrm{Ch}$ release and cGMP levels. The cells were preincubated for $3 \mathrm{hr}$ with increasing doses of tetanus toxin at $37^{\circ} \mathrm{C}$. At the end of the incubation period ${ }^{3} \mathrm{H}-\mathrm{ACh}$ release and cGMP levels, in response to stimulation with $30 \mathrm{~mm} \mathrm{~K}$ ', were measured from the same culture wells. Shown are the release of ${ }^{3} \mathrm{H}-\mathrm{ACh}(\boldsymbol{)})$ and cGMP accumulation $(\mathrm{O})$ after 2 min incubations expressed as a percentage of the maximal value in control cultures that were not exposed to toxin. These results are the means of 2-3 experiments each performed in sextuplicate.

Detailed examination of the development of toxin sensitivity in NGF-treated cultures revealed that cells became sensitive to tetanus toxin only after culturing in NGF for at least $8 \mathrm{~d}$ (Fig. 6). We previously reported that day 6 NGF-treated cultures were poor in releasing $\mathrm{ACh}$ in response to veratridine (Sandberg et al., 1989a). Likewise, day 6 cultures were poor at releasing ${ }^{3} \mathrm{H}$ ACh (Fig. $6 \mathrm{~A}$ ) and accumulating cGMP in response to barium (Fig. $6 B$ ). The characteristics of ${ }^{3} \mathrm{H}-\mathrm{ACh}$ release and cGMP accumulation in day 3 cells were similar to those observed in densely grown cells. This may reflect the fact that day 3 cells retain some characteristics of dense cells since day 0 cells were subcultured from confluent flasks. In summary, it is clear that the differentiation state of the cells determines the sensitivity of PC12 cultures to tetanus toxin when assessed either at the

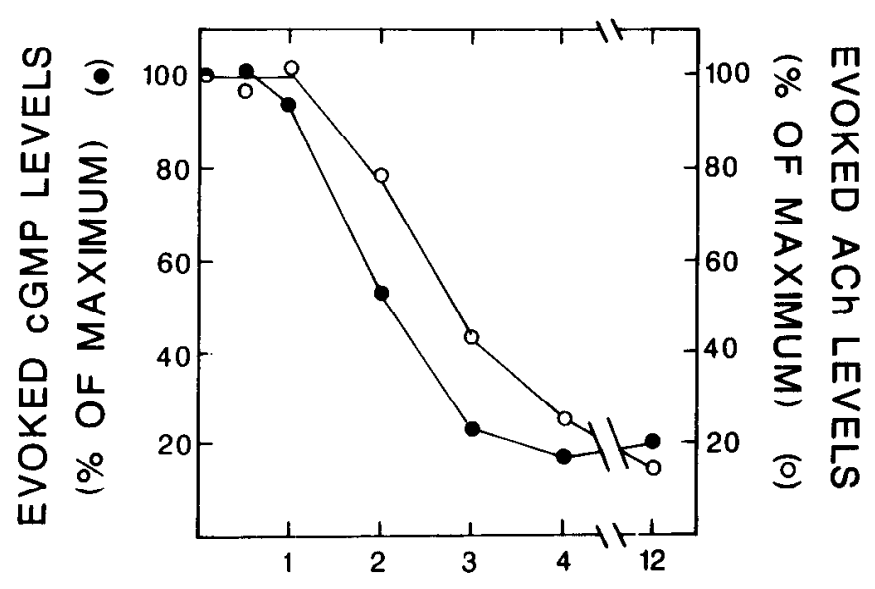

INCUBATION TIME (HOURS)

Figure 4. Time course of tetanus toxin action on $\mathrm{K}^{+}$-stimulated ${ }^{3} \mathrm{H}$ ACh release and cGMP levels. ${ }^{3} \mathrm{H}$-Ch-prelabeled PC12 cells were incubated with $10 \mathrm{~nm}$ tetanus toxin at $37^{\circ} \mathrm{C}$. At various times the cultures were removed from the incubator and the $\mathrm{K}^{+}$-evoked release of ${ }^{3} \mathrm{H}-\mathrm{ACh}$ $(\mathrm{O})$ and CGMP accumulation (๑) levels were measured in the same culture wells. These results are the means of 2-3 experiments, each performed in sextuplicate. 


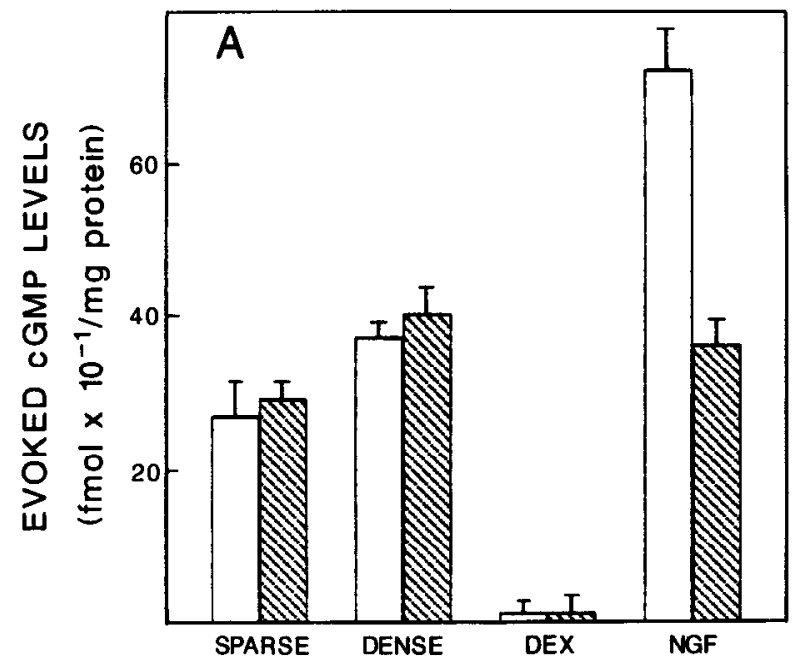

DIFFERENTIATION CONDITIONS

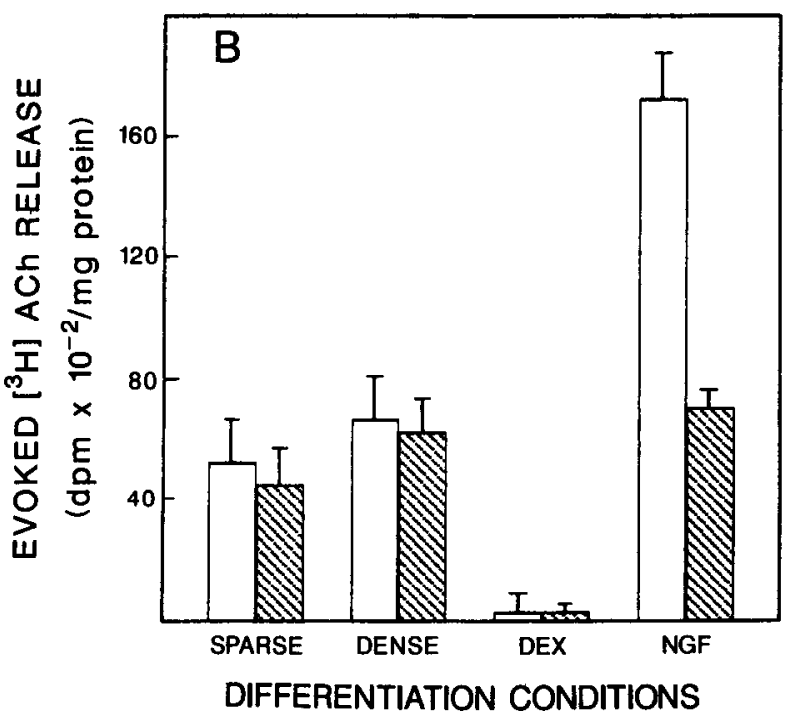

Figure 5. Effect of tetanus toxin on $\mathrm{Ba}^{2+}$-evoked ${ }^{3} \mathrm{H}-\mathrm{ACh}$ release and cGMP levels in PC12 cells grown under various differentiation conditions. $\mathrm{Ba}^{2+}$-evoked cGMP accumulation $(A)$ or ${ }^{3} \mathrm{H}$-ACh release $(B)$ were measured. Evoked ${ }^{3} \mathrm{H}-\mathrm{ACh}$ release and $\mathrm{cGMP}$ levels were measured in the presence (hatched bars) and absence (open bars) of tetanus toxin (10 $\mathrm{nM}, 16-18 \mathrm{hr}$ preincubations at $37^{\circ} \mathrm{C}$ ) from $\mathrm{PC} 12$ cells grown under a variety of conditions: $14 \mathrm{~d}$ at $5 \times 10^{4}$ cells $/ 10 \mathrm{~cm}^{2}$, in the presence of $1 \times 10^{-6} \mathrm{M}$ dexamethasone $(D E X) ; 14 \mathrm{~d}$ at $5 \times 10^{4}$ cells $/ 10 \mathrm{~cm}^{2}$, in the presence of $100 \mathrm{ng} / \mathrm{ml}$ nerve growth factor $(N G F) ; 7 \mathrm{~d}$, at high density $\left(5 \times 10^{5}\right.$ cells $\left./ 10 \mathrm{~cm}^{2}\right)(D E N S E)$; or at low density $\left(5 \times 10^{4}\right.$ cells $/ 10$ $\left.\mathrm{cm}^{2}\right)(S P A R S E)$. The results are the means of 2-3 experiments, each performed in sextuplicate $( \pm S E M)$.

functional or biochemical level. These results provide further circumstantial evidence for a close relation between the inhibitory effects of toxin on both $\mathrm{ACh}$ release and cGMP elevation.

\section{Reversibility of tetanus toxin action by cGMP analogs}

If the effects of tetanus toxin on neurotransmitter release are causally related to the observed inhibition in stimulus-evoked cGMP accumulation, then it should be possible to reverse the blockade of neurotransmitter release by increasing cGMP levels in the toxin-treated $\mathrm{PC1} 2$ cells. Accordingly, toxin-treated cells
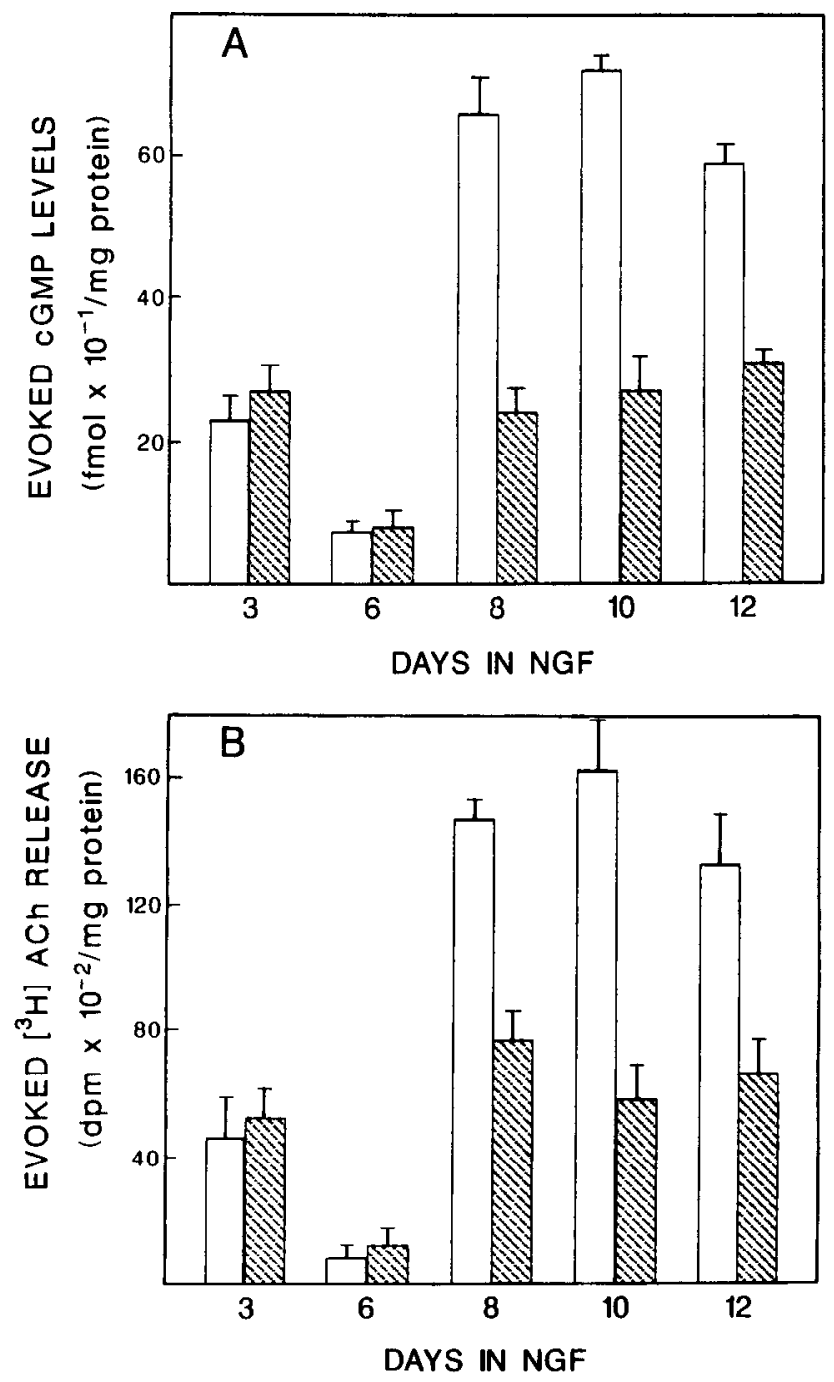

Figure 6. Effect of tetanus toxin on $\mathrm{Ba}^{3+}$-evoked ${ }^{3} \mathrm{H}-\mathrm{ACh}$ release and cGMP levels from PC12 cells as a function of days in NGF. Evoked ${ }^{3} \mathrm{H}$-ACh release $(B)$ and cGMP levels $(A)$ were measured as a function of culture days in NGF $(100 \mathrm{ng} / \mathrm{ml})$ in the presence (hatched bars) and absence (open bars) of tetanus toxin (10 $\mathrm{nM}, 16-18 \mathrm{hr}$ incubation at $37^{\circ} \mathrm{C}$ ). The results are the means of $2-3$ experiments, each performed in sextuplicate $( \pm \mathrm{SEM})$.

were challenged with $100 \mu \mathrm{M} 8 \mathrm{Br}-\mathrm{cGMP}$ during the last $15 \mathrm{~min}$ of a $4 \mathrm{hr}$ toxin incubation, before assaying for neurotransmitter release. Under these conditions, the evoked release of ${ }^{3} \mathrm{H}-\mathrm{ACh}$ was restored to $65 \%$ of control (toxin free) levels (Fig. 7). In contrast, 8Br-cGMP had no significant effect on either spontaneous or evoked ACh release in control PC12 cells (Fig. 7). Control experiments demonstrated that the observed reversal of toxin action cannot be explained by increased cell lysis. The amount of lactate dehydrogenase released into the media in the presence of $8 \mathrm{Br}-\mathrm{cGMP}$ was nearly identical to that released in control cultures (data not shown). The effect of this CGMP analog was dose-dependent (Fig. 7, inset). In 15 min preincubations, significant effects were seen at $10 \mu \mathrm{M}$, and the half-maximal effect was observed at approximately $50 \mu \mathrm{M}$.

The specificity of the reversal effect was characterized as shown in Figure 8. All cGMP analogs that were tested were found to be effective in reversing the toxin-mediated inhibition of ${ }^{3} \mathrm{H}$ - 


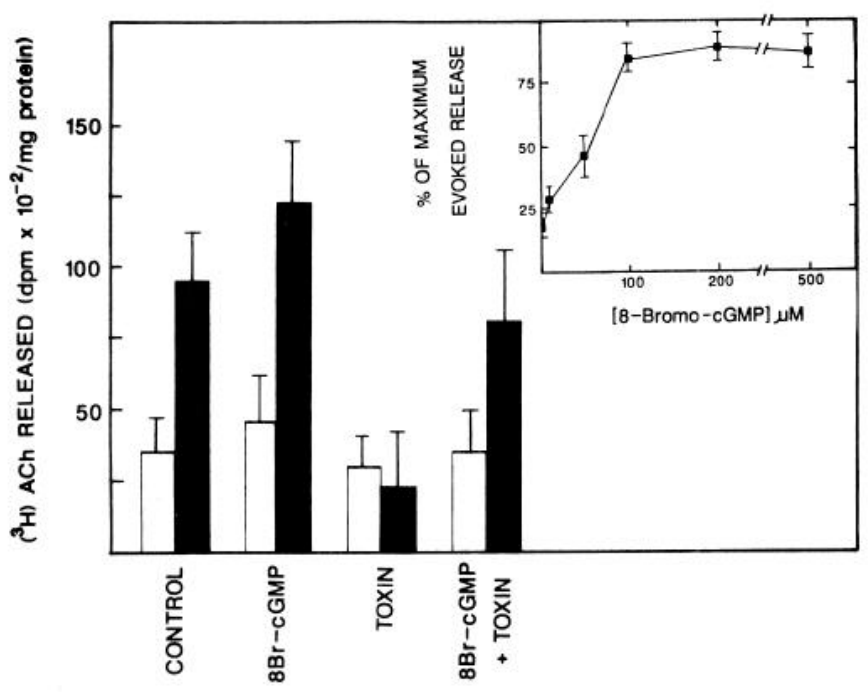

Figure 7. $8 \mathrm{Br}-\mathrm{cGMP}$ reverses the action of tetanus toxin on $\mathrm{PC} 12$ cells. Spontaneous (open bars) and veratridine-evoked (solid bars) ${ }^{3} \mathrm{H}-$ $\mathrm{ACh}$ release was measured in ${ }^{3} \mathrm{H}$-Ch-prelabeled $\mathrm{PC} 12$ cells. Both spontaneous and evoked ${ }^{3} \mathrm{H}-\mathrm{ACh}$ release were measured following 4 different preincubation conditions: $C O N T R O L$, no additions; $8 \mathrm{Br}-c G M P, 15$ min incubation at $37^{\circ} \mathrm{C}$ with $100 \mu \mathrm{M} 8$-Br-cGMP; TOXIN, $4 \mathrm{hr}$ incubation at $37^{\circ} \mathrm{C}$ with $4 \mathrm{nM}$ tetanus toxin; $8 \mathrm{Br}-c G M P+T O X I N$, after a $3.75 \mathrm{hr}$ incubation at $37^{\circ} \mathrm{C}$ with $4 \mathrm{~nm}$ tetanus toxin, the cells were incubated with $100 \mu \mathrm{M} 8$-Br-cGMP for $15 \mathrm{~min}$. The results are the means of 6 experiments each performed in triplicate $( \pm \mathrm{SEM})$. Inset, Dose-response curve for the ability of 8 -Br-cGMP to reverse the inhibition of ${ }^{3} \mathrm{H}-\mathrm{ACh}$ release induced by tetanus toxin in PC1 2 cells. PC12 cells were cultured in the presence of NGF and ${ }^{3} \mathrm{H}-\mathrm{ACh}$ release was measured as described in Experimental procedures. During the last 15 min of the $4 \mathrm{~nm}$ tetanus toxin $4 \mathrm{hr}$ incubation, increasing concentrations of 8 -Br-cGMP were added to the PC12 cells. The results are the means of 6 experiments, each performed in triplicate $( \pm$ SEM).

ACh release (Fig. 8). In contrast, analogs of cAMP and other cyclic nucleotides, as well as acyclic analogs of guanine phosphates, at concentrations as high as $1 \mathrm{~mm}$, were not effective in reversing the action of tetanus toxin (Fig. 8). Control experiments indicated that the binding of ${ }^{125} \mathrm{I}$-tetanus toxin to these cells was not affected by cyclic guanine nucleotides (data not shown). These findings demonstrate that the ability to reverse the blockade of neurotransmitter release induced by tetanus toxin is specific to cGMP analogs.

\section{Effects of toxin on cGMP metabolism}

The 2 simplest explanations for the finding that tetanus toxin prevents the depolarization-induced increase in cGMP are that (1) tetanus toxin inhibits the production of cGMP in response to depolarizing stimuli by interfering with guanylate cyclase activity, as suggested by Smith and Middlebrook (1985); or (2) tetanus toxin stimulates the breakdown of cGMP by activating a phosphodiesterase. We examined the effects of tetanus toxin treatment on guanylate cyclase activity in soluble and particulate fractions as well as whole-cell homogenates from PC12 cells. As shown in Table 3, when cells were treated with toxin under conditions in which $\mathrm{ACh}$ release is inhibited, there was no detectable change in enzyme activity in any of these subcellular fractions. Thus, under the conditions used, we could not find experimental evidence to support the first hypothesis.

In the next series of experiments, the potential importance of

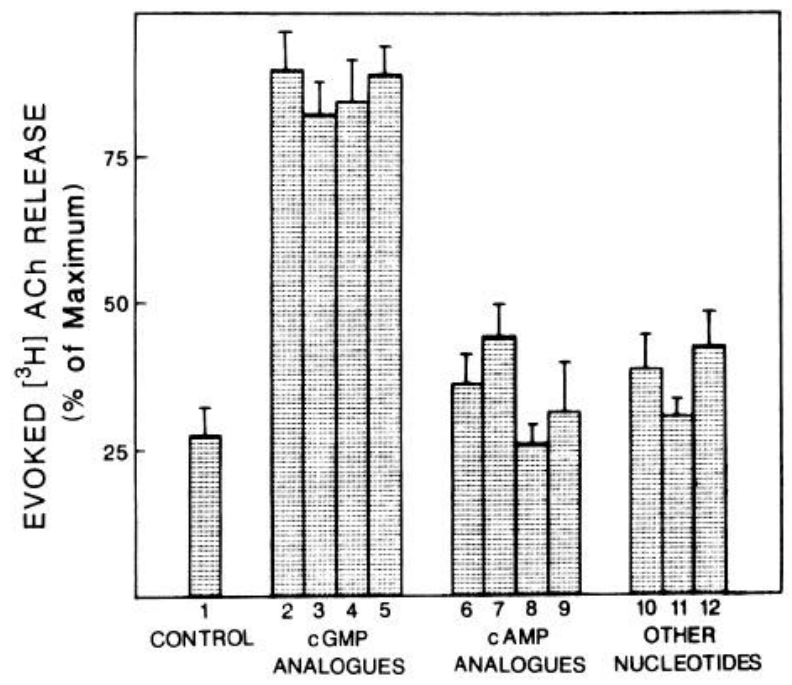

Figure 8. Specificity of nucleotide analogs to reverse the action of tetanus toxin on PC12 cells. Various nucleotides were added to the PC1 2 cells during the last $15 \mathrm{~min}$ of the $4 \mathrm{~nm}$ tetanus toxin $4 \mathrm{hr}$ incubation at $37^{\circ} \mathrm{C}: 1$, control, no nucleotides; $2,100 \mu \mathrm{M} 8$-Br-cGMP; 3, 1 mм $N^{6}, 2^{\prime}$ - $O$-dibutyryl-cGMP; 4, 1 mM $N^{2}$-monobutyryl-cGMP; 5, 1 mм $O^{2}$-monobutyryl-cGMP; 6, $100 \mu \mathrm{M} 8$-Br-cAMP; 7, $1 \mathrm{~mm} N^{6}$, 2'-OP-dibutyryl-cAMP; $8,1 \mathrm{mM} N^{2}$-monobutyryl-cAMP; 9, $1 \mathrm{~mm}$ $\mathrm{O}^{2}$-monobutyryl-cAMP; $10,100 \mu \mathrm{M} 8$-Br-inosine-cyclic monophosphate; 11, $1 \mathrm{~mm} 8$-Br-guanosine monophosphate; $12,1 \mathrm{~mm} 8$-Br-guanosine. ${ }^{3} \mathrm{H}$-ACh release is expressed as a percentage of the maximum evoked ${ }^{3} \mathrm{H}$-ACh release in controls which were prepared in an identical manner except that toxin was omitted from the incubations.

the second hypothesis was examined. PC1 2 cells were incubated overnight with tetanus toxin and were then treated for $15 \mathrm{~min}$ with either of 2 phosphodiesterase inhibitors, IBMX or zaprinast. The latter is reported to be selective for cGMP-degrading phosphodiesterases (Weishaar et al., 1985; Luginer et al., 1986). Treatment with IBMX or zaprinast had a small but reproducible effect on basal cGMP, increasing levels by 15 and $19 \%$, respectively (data not shown). As shown in Figure $9 A$, these agents had a greater effect on stimulus-evoked cGMP elevation. IBMX and zaprinast increased these values by 50 and $115 \%$, respectively, in control cultures. The important finding was that in

$\begin{aligned} & \text { Table 3. Effect of tetanus toxin on guanylate cyclase activity in } \\
& \text { PC12 cells }\end{aligned}$
\begin{tabular}{lll} 
& $\begin{array}{l}\text { Guanylate cyclase activity } \\
\text { (pmol cGMP/min/mg } \\
\text { protein) }\end{array}$ \\
\cline { 2 - 3 } & Control & $\begin{array}{l}\text { + Tetanus } \\
\text { toxin }\end{array}$ \\
Tissue preparation & 232 & 244 \\
Total cell homogenate & 408 & 392 \\
Soluble fraction & 224 & 197 \\
Particulate fraction & &
\end{tabular}

PC12 cells were cultured as described in Materials and Methods. The cultures were treated with $10 \mathrm{nM}$ tetanus toxin in DMEM containing $0.25 \%$ BSA. At the end of the incubation, the cells were homogenized in $0.25 \mathrm{M}$ sucrose, $50 \mathrm{~mm}$ Tris,

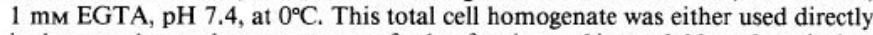
in the guanylate cyclase assay or was further fractionated into soluble and particulate fractions by centrifugation at $100,000 \times g$ for $1 \mathrm{hr}$. The fractions were assayed for guanylate cyclase activity. The results are the means of 3 experiments with a variation of $10 \%$ or less. 

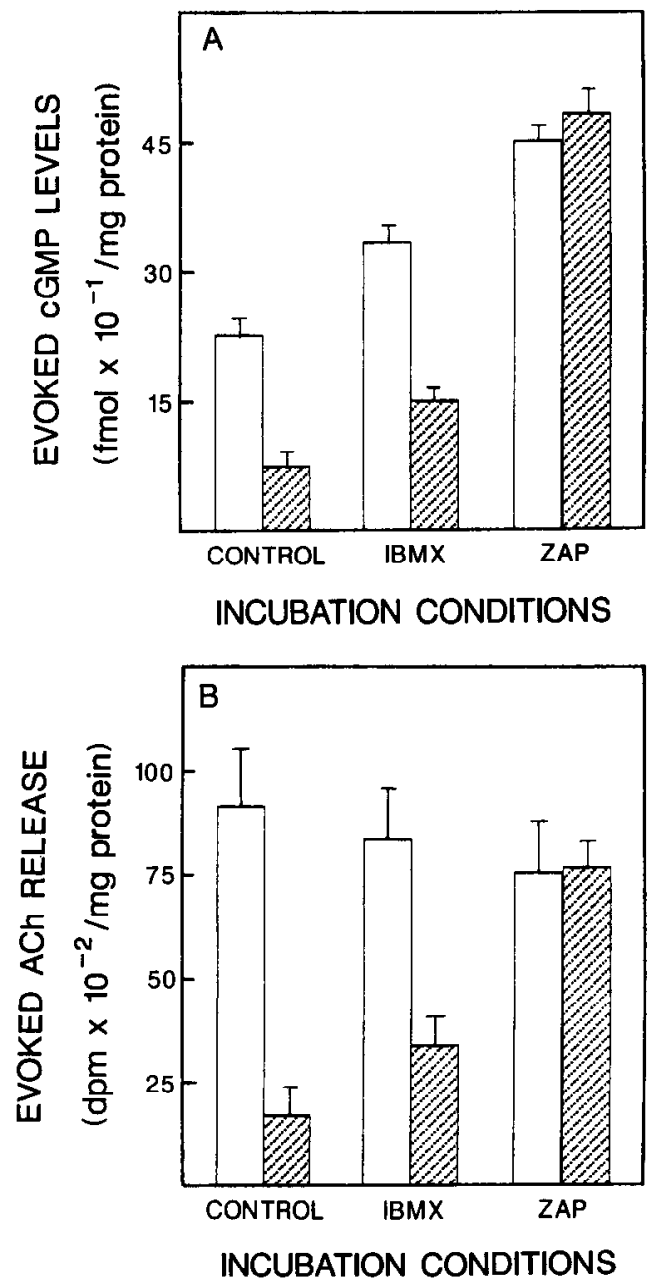

Figure 9. Reversibility of tetanus toxin action on PC12 cells by phosphodiesterase inhibitors. $A$, Evoked levels of cGMP were measured on cells preincubated $\left(16-18 \mathrm{hr}\right.$ at $\left.37^{\circ} \mathrm{C}\right)$ with (hatched bars) and without (open bars) $10 \mathrm{~nm}$ tetanus toxin. B, Levels of evoked ${ }^{3} \mathrm{H}-\mathrm{ACh}$ release measured with these same cells. Evoked cGMP levels and evoked ${ }^{3} \mathrm{H}-$ ACh release levels are defined as total stimulated levels minus basal levels. Basal levels were measured in the presence of "control release buffer," and stimulated levels were measured in the presence of "depolarizing release buffer" (control release buffer supplemented with 200 $\mu \mathrm{M}$ veratridine). Before cells were exposed to release buffers, they werc preincubated for 15-20 min with the following buffers: CONTROL, DMEM alone; $I B M X$, DMEM supplemented with $100 \mu \mathrm{M}$ IBMX; $Z A P$, DMEM supplemented with $100 \mathrm{nM}$ zaprinast. These results are the means of 2-3 experiments, each performed in sextuplicate $( \pm$ SEM).

toxin-treated cultures IBMX partially reversed, and zaprinast fully reversed, the inhibition of cGMP elevation (Fig. 9A). Evoked ${ }^{3} \mathrm{H}-\mathrm{ACh}$ release was measured from these same cells as shown in Figure $9 B$. Neither IBMX nor zaprinast had any effect on $\mathrm{Ba}^{2+}$-evoked $\mathrm{ACh}$ release from control cultures. However, IBMX and zaprinast restored $\mathrm{ACh}$ release levels by 16 and $100 \%$, respectively, when compared with toxin-free cultures.

The experiments described in Figure 9 were performed using barium as a stimulant. However, zaprinast was also effective in reversing the effects of tetanus toxin when the cells were depolarized using other conditions (Table 4 ). The results demonstrate a correlation between the ability of phosphodiesterase inhibitors to restore cGMP levels and to restore evoked $\mathrm{ACh}$ release levels in tetanus toxin-poisoned cultures.

\section{Discussion}

Although the mechanism of action of tetanus toxin is unknown, it has been recognized for some time that the Clostridial neurotoxins, including tetanus toxin, are promising tools to study mechanisms of excitation-secretion coupling in neurons (Habermann and Dreyer, 1986; Simpson, 1986). In a previous report, we have shown that tetanus toxin is a potent inhibitor of ACh release from cultures of $\mathrm{PC} 12$ cells and is an excellent model system of toxin studies (Sandberg et al., 1989a). The major thrust of the current work was to exploit the PCl 2 celltetanus toxin system in order to identify the underlying molecular mechanism of tetanus toxin inhibition of neurotransmitter release. The major conclusions from this work are: (1) tetanus toxin inhibits stimulus-evoked cGMP levels in PC1 2 cells under conditions in which it blocks stimulus-evoked ACh release; (2) the inhibitory effects of tetanus on ACh release are rapidly reversed with cGMP analogs; and (3) a cGMP specific phosphodiesterase is a possible site of action for tetanus toxin since phosphodiesterase inhibitors restored stimulus-evoked ACh release and cGMP levels in a similar manner.

Our results demonstrate that intracellular cGMP levels increase when PC12 cells are depolarized. The evoked levels of cGMP peaked within $20-60 \mathrm{sec}$ with various stimuli, which is consistent with the time course of neurotransmitter release under these conditions (Sandberg et al., 1989a). Further support for a link between neurosecretion and cGMP levels was provided by results from experiments where cGMP levels and $\mathrm{ACh}$ release were measured in the same cells. Although these parameters had to be measured over different time intervals in these experiments, the results clearly demonstrate a qualitative relation between evoked cGMP levels and $\mathrm{ACh}$ release under a variety of conditions of depolarization and cell growth (Figs. 36). It has been recognized for many years that cGMP levels in neural tissues increase in response to depolarizing stimuli (Nathanson, 1977; Ferrendelli et al., 1978; Study et al., 1978). However, the functional significance of this effect has not been elucidated. These initial results provided circumstantial evidence for a role of this cyclic nucleotide in neurosecretion.

The relationship between cGMP levels and neurotransmitter release was further underscored by the observation that tetanus toxin inhibited both processes. Under the experimental conditions used, there is a qualitative correlation between the toxin dose-inhibition curves and the time course for the development of the inhibitory responses of CGMP accumulation and ACh release in PC12 cells (Figs. 3, 4). We have previously reported that only NGF-treated PC1 2 cells were sensitive to tetanus toxin (Sandberg et al., 1989a). The same relation was found here for the toxin inhibition of evoked-cGMP accumulation. Although the subject of many studies, the molecular mechanisms of tetanus toxin have remained elusive. These results provide important new evidence for the underlying mechanism of action for this toxin and support the view that tetanus toxin interferes with cGMP metabolism in PC12 cells.

Substantial support for this relationship was obtained in experiments in which $8 \mathrm{Br}-\mathrm{cGMP}$ and other cyclic guanine nucleotides were able to reverse the blockade of $\mathrm{ACh}$ release induced by tetanus toxin (Figs. 7, 8). These cyclic nucleotides were not secretagogues alone, since they had minimal effects on $\mathrm{ACh}$ release from control $\mathrm{PC} 12$ cells in the absence of other stimuli. However, their ability to rapidly reverse the inhibitory effects on toxin-treated cells was striking since the inhibitory effects of 
Table 4. Reversal of tetanus toxin action by zaprinast

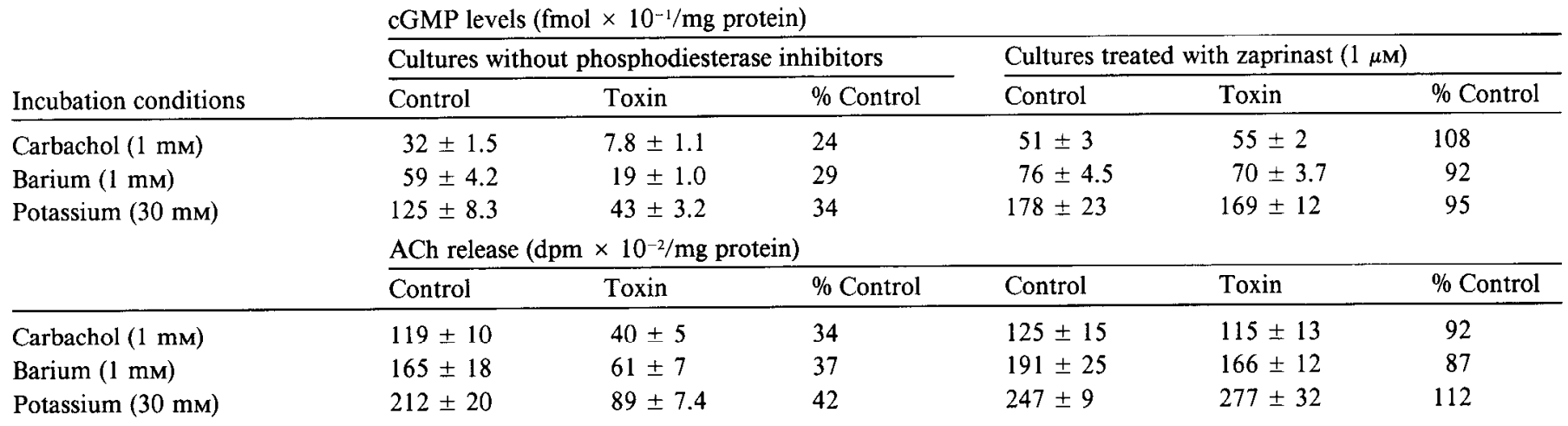

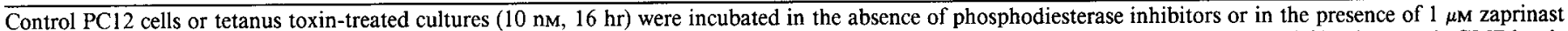

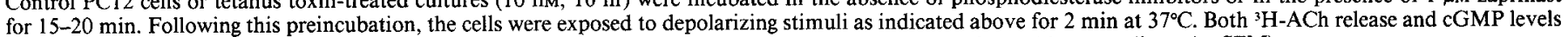
were measured in the same culture. The results are reported as the means of 2-3 experiments, each performed in scxtuplicate ( \pm SEM).

tetanus, once established, are stable for days in PC12 cells and in vivo (Simpson, 1986; Sandberg et al., 1989a). Only short-term incubations (on the order of minutes) with micromolar doses of these agents were required to reverse the tetanus toxin-induced inhibition of $\mathrm{ACh}$ release. Thus, not only do these results reveal a relation between toxin action and cGMP, but to our knowledge, this is the first demonstration of significant reversal of the effects of tetanus toxin once they have been established in neural cells.

Results reported here identify the metabolic pathway for cGMP as a potential site of action of tetanus toxin. Preliminary studies have revealed that guanylate cyclase activity is not inhibited in intoxicated PC12 cells. Although we cannot rigorously rule out a possible role for this enzyme in toxin action, all of the evidence reported here is consistent with the view that the degradation of cGMP is stimulated in toxin-treated cells. The phosphodiesterase inhibitors, IBMX and zaprinast, were effective in reversing the effects of tetanus toxin on both the inhibition of evoked cGMP accumulation and ACh release in a similar manner (Fig. 9). IBMX, a wide-spectrum, rather low-affinity phosphodiesterase inhibitor (Weishaar et al., 1985), partially restored cGMP levels and $\mathrm{ACh}$ release. Zaprinast has been reported to be specific for cGMP-degrading phosphodiesterases in a number of diverse tissues (Windquist et al., 1984; Weishaar et al., 1985; Luginer et al., 1986). Results reported here reveal that this agent was very effective in elevating cGMP levels in control PC12 cells as well. This compound completely restored the stimulusevoked cGMP response and $\mathrm{ACh}$ release after it was applied for $15 \mathrm{~min}$ to intoxicated cells (Fig. 9, Table 3). While it is possible that the hydrophobic agents, $8 \mathrm{Br}$-cGMP and zaprinast, act through nonspecific mechanisms, the observation that the effects of tetanus can be reversed by these 2 distinctly different chemicals that share the common property of elevating cGMP levels in PC12 cells strongly argues against nonspecific mechanisms.

A minimal interpretation of these results is that tetanus toxin acts directly or indirectly to increase the activity of cGMP phosphodiesterase in PC12 cells. Multiple forms of phosphodiesterases, which are differentially inhibited by various drugs, have been identified in many tissues (Beavo et al., 1982; Windquist et al., 1984; Weishaar et al., 1985). It is not clear which isozyme may be involved in tetanus toxin action. The fact that basal
cGMP levels are not significantly different in control and toxintreated cells suggests that such an enzymatic activity may predominate during depolarization. The particular target enzyme remains to be identified, and zaprinast may prove to be a valuable probe for such studies.

The results reported here provide compelling evidence that cGMP plays an essential role in neurotransmitter release. It is interesting to speculate on the functional role of cGMP in this process. Since neither $8 \mathrm{Br}$-cGMP nor zaprinast stimulated ACh release directly, it is not likely that cGMP alone is the intracellular messenger that evokes secretion. The implication is that in order to elicit neurotransmitter release, cGMP-mediated events must work in concert with other events that are triggered by depolarization. At present the target for CGMP in neurosecretion is not known. However, tetanus toxin is a promising tool to identify this mechanism.

\section{References}

Beavo, J. A., R. S. Hansen, S. A. Harrison, R. L. Hurwitz, T. J. Martins, and M. C. Mumbry (1982) Identification and properties of cyclic nucleotide phosphodiesterases. Mol. Cell. Endocrinol. 28: 387-405.

Bergey, G. K., R. L. MacDonald, W. H. Habig, M. C. Hardegree, and P. G. Nelson (1983) Tetanus toxin convulsant action on mouse spinal cord neurons in culture. J. Neurosci. 3: 2310-2323.

Collingridge, G. L., G. G. S. Collins, J. Davies, T. A. James, M. J. Neal, and $P$. Tongroach (1980) Effect of tetanus toxin on transmitter release from substantia nigra and striatum in vitro. J. Neurochem. 34: 540-547.

Dreyer, F., A. Mallart, and J. L. Brigant (1983) Botulinum A toxin and tetanus toxin do not affect presynaptic membrane currents in mammalian motor nerve endings. Brain Res. 270: 373-375.

Eugster, E., K. Sandberg, and T. B. Rogers (1986) The effect of differentiation on guanylate cyclase activity and cGMP levels in PC12 cells. Soc. Neurosci. Abstr. 14: 822.

Ferrendelli, J. A., D. A. Kinscherf, and M. M. Chang (1978) Distribution and regulation of cyclic GMP in the central nervous system. Adv. Cyclic Nucleotide Res. 9: 453-464.

Goldberg, N. D., and M. K. Haddox (1977) Cyclic GMP metabolism and involvement in biological regulation. Annu. Rev. Biochem. 46: 823-896.

Green, L. A., and A. S. Tischler (1982) PC12 pheochromocytoma cultures in neurobiological research. Adv. Cell. Neurobiol. 3: 373414.

Habermann, E., and F. Dreyer (1986) Clostridial neurotoxins: Handling and action at the cellular and molecular level. Curr. Topics Microbiol. Immunol. 129: 93-179.

Luginer, C., P. Schoeffter, A. LeBec, E. Strouthou, and J. C. Stoclet 
(1986) Selective inhibition of cyclic nucleotide phosphodiesterase of human, bovine and rat aorta. Biochem. Pharmacol. 35: 1743-1751.

Mellanby, J., and J. Green (1981) How does tetanus toxin act? Neuroscience $6: 281-300$.

Nathanson, J. A. (1977) Cyclic nucleotides and nervous system function. Physiol. Rev. 57: 158-256.

Osborne, R. H., and H. F. Bradford (1973) Tetanus toxin inhibits amino acid release from nerve endings in vitro. Nature [New Biol.] 244: $157-158$.

Sandberg, K., C. J. Berry, and T. B. Rogers (1989a) Studies on the intoxication pathway of tetanus toxin in the rat pheochromocytoma (PC12) cell line. J. Biol. Chem. 264: 5679-5686.

Sandberg, K., C. J. Berry, E. Eugster, and T. B. Rogers (1989b) Studies on the molecular mechanism of action of tetanus toxin: A role for cGMP in the release of acetylcholine from PC1 2 cells. Proceedings of the 8th International Conference on Tetanus (Leningrad, Russia), B. Bizzini and G. Nistico, eds., Pitagora Press, Bologna, Italy (in press).

Schmitt, A., F. Dreyer, and C. John (1981) At least three sequential steps are involved in the tetanus toxin-induced block of neuromuscular transmission. Naunyn-Schmiedeberg's Arch. Pharmacol. 317: 326-330.

Schwab, M. E., and H. Thoenen (1976) Electron microscopic evidence for a transsynaptic migration of tetanus toxin in spinal cord motoneurons: An autoradiographic and morphometric study. Brain Res. 105: 213-224.
Simpson, L. L. (1986) Molecular pharmacology of botulinum toxin and tetanus toxin. Annu. Rev. Pharmacol. Toxicol. 26: 427-454.

Smith, L. A., and J. L. Middlebrook (1985) Botulinum and tetanus neurotoxins inhibit guanylate cyclase activity in synaptosomes and cultured nerve cells. Toxicon 23: 611a.

Snider, R. M., M. McKinney, C. Forray, and E. Richelson (1984) Neurotransmitter receptors mediate cyclic GMP formation by involvement of arachidonic acid and lipoxygenase. Proc. Natl. Acad. Sci. USA 81: 3905-3909.

Study, R. E., X. O. Breakfield, T. Bartfai, and P. Greengard (1978) Voltage-sensitive calcium channels regulate guanosine $3^{\prime}, 5^{\prime}$-cyclic monophosphate levels in neuroblastoma cells. Proc. Natl. Acad. Sci. USA 75: 6295-6299.

Walton, K. M., K. Sandberg, T. B. Rogers, and R. L. Schnaar (1988) Complex ganglioside expression and tetanus toxin binding by $\mathrm{PC1} 2$ pheochromocytoma cells. J. Biol. Chem. 263: 2055-2063.

Weishaar, R. E., M. H. Cain, and J. A. Bristol (1985) A new generation of phosphodiesterase inhibitors: Multiple molecular forms of phosphodiesterase and the potential for drug selectivity. J. Med. Chem. 28: 537-545.

Windquist, R. J., E. P. Faison, S. A. Waldman, K. Schwartz, F. Murad, and R. M. Rappoport (1984) Atrial natriuretic factor elicits an endothelial-independent relaxation and activates guanylate cyclase in vascular smooth muscle. Proc. Natl. Acad. Sci. USA 81: 7661-7664. 